\title{
Current Debates About the Approach of the "Munich School" and Further Perspectives on the Interdisciplinary Study of the History of World Christianity
}

\author{
ADRIAN HERMANN \\ UNIVERSITÄT HAMBURG \\ CIPRIAN BURLACIOIU \\ LUDWIG-MAXIMILIANS-UNIVERSITÄT MÜNCHEN
}

ABSTRACT: The research projects and publications of Klaus Koschorke and the "Munich School of World Christianity" have sparked intense debate over the last two decades. The first section of this contribution discusses some of these reactions and critiques, as well as Koschorke's responses. It addresses questions about the idea of "polycentricity," alternative ways of conceptualizing a variety of Christian centers, the relationship of Koschorke's approach to the concept of transculturation, and the need for greater diversity and inclusiveness in scholarly perspectives. The second section outlines some important issues regarding challenges and further perspectives for a future history of world Christianity. It touches on the question of the geographic horizon(s) of this approach, debates about "transmission" and "appropriation," and the role of the anthropology of Christianity in describing the fluid character of Christian movements. In addition, it addresses the problem of how to relate the history of world Christianity to a global history of religion, as well as the importance of considering issues of migration as central to our understanding of Christianity.

KEYWORDS: history of world Christianity, challenges, global history of religion, anthropology of Christianity, Munich School of World Christianity

"World Christianity" as an issue of academic study is increasingly seen as highly relevant not only in the United States and the English-speaking 
academia but also in continental Europe. ${ }^{1}$ So, for example, a new professorship on Außereuropäische Christentumsgeschichte (non-European Christianity) has recently been established in Basel, as well as a chair for the "Study of World Christianity" in Utrecht. One of the places in which this theme has been a central topic of study already for more than twenty years, however, is the chair for Early and Global History of Christianity at the University of Munich, held by Klaus Koschorke from 1993 to 2013. Koschorke and the group of scholars working in (or cooperating with) Munich have contributed significantly and given new impulses to the ongoing debate about a future history of world Christianity. In this issue of the Journal of World Christianity the work of Koschorke and the other members of what American colleagues have called the "Munich School of World Christianity" is being presented to a broader Anglophone audience.

It might be useful to quickly recall three central convictions that have guided the program of the "Munich School" (which are presented in detail in Koschorke's contribution to this issue): First, we urgently need new and enlarged maps of the history of world Christianity that allow us to understand and describe the denominational, cultural, and regional diversity of Christianity as part of an integrated whole. This global perspective cannot consist in a mere collection of isolated regional histories but has to be the result of comparative studies that take into account similar as well as diverging developments of Christian history in different regions of the world and identify common themes, issues, and challenges. Second, the history of world Christianity is characterized by polycentric structures, not just over the last two centuries but already from its very beginning. Third, the Munich approach suggests that we understand the history of world Christianity as a history of multidirectional transcontinental interactions by focusing especially on transregional and transcontinental links between Christian movements and churches in different parts of the world. Particularly important in this context is the reconstruction of early instances of South-South connections, which run counter to the prevailing narratives that put the history of Western missionary endeavors at the center of world Christianity's history. As presented in detail in the introduction to this issue, this concept of a polycentric and global history of world Christianity has served as the starting point of the various research projects and publications of Koschorke and other scholars working in Munich over the last twenty years, the most important of which are two documentary source books, the six volumes containing the conference proceedings of the International Munich-Freising Conferences, a festschrift for Koschorke's sixtyfifth birthday, and the individual monographs by the other members of the Munich School. ${ }^{2}$ 


\section{The "Munich School" Approach to the History of World Christianity: Reactions, Critiques, Responses}

The projects and publications of Klaus Koschorke and the "Munich School of World Christianity" have sparked intense discussions over the last two decades. As Thomas Kaufmann, one of the leading German Reformation historians, has stated, they already had an important and transforming impact on the discipline of church history as taught at faculties of Protestant theology in Germany. ${ }^{3}$ The academic debate about the Munich School takes place in various venues but especially in the festschrift and the conference proceedings of the Sixth International Munich-Freising Conference. ${ }^{4}$ Some of these reactions and critiques, as well as Koschorke's responses, will be presented below. ${ }^{5}$

\subsection{Polycentric Structures in All Periods of the History of Christianity}

"Polycentric structures are of basic importance both for the early as well as for the global history of Christianity" (MFC VI, 382) - thus writes Martin Wallraff, who teaches early church history at the University of Basel. At the same time, he identifies the "interplay of polycentricism and cohesion" (MFC VI, 382) as a constitutive characteristic of the history of Christianity in its different epochs. Speaking of "polycentric structures" is not just a new and different way of talking about "pluralism" but, rather, highlights aspects of "interaction." In Wallraff's opinion, the particular interplay between "early" church history and "global" church history-as realized at the Munich chair-also becomes visible in the high level of internationalization of the two disciplines. At the same time, such a focus on regional centers of expansion, local variants of Christianity, and indigenous initiatives should always be the basis of writing the history of Christianity as a global religion, not only of the last fifty years but of its whole history since its early beginnings.

\subsection{Is the Concept of Polycentricity Also Relevant for Catholic Mission History?}

In his contribution to the festschrift, Mariano Delgado-a specialist in Latin American church history-argues that in regard to early modern Catholic missions one could not speak of "polycentric structures" but, rather, of a "pluriformity of strategies of mission." ${ }^{6}$ This observation, however, as Koschorke states in his retrospective on the proceedings of the Sixth International Munich-Freising Conference, does not imply a counternotion to the concept of "polycentricity" but contributes, rather, to its clarification and further refinement (MFC VI, 445). It refers to the level of European missionary activities - in Delgado's case in the Philippines - where the Catholic orders (Franciscans, Dominicans, Jesuits) could apply lessons learned from years of missionary experience in colonial 
Spanish America. It therefore enables a more detailed description of European mission history, which, however, should be understood only as a subsegment of the much broader spectrum of the history of world Christianity, which also has to take into account other-indigenous-actors and various noncolonial or extracolonial contexts.

In sixteenth-century India, for example, three forms of Christian presence can be distinguished: in addition to the traditional Thomas Christians-who had been living in the country for centuries-and the colonial Catholicism of the Portuguese newcomers, the mass conversion and self-Christianization of the South Indian fisher caste of the Paravas has to be taken into account. These events also led to a regional self-extension of Christianity into other regions (such as Mannar in northern Sri Lanka)_-sometimes long before the Portuguese arrived there. This constellation of three forms of Christianity (precolonial, colonial, nonmissionary initiatives) can equally be found in other regions of Asia and Africa at the time. It demonstrates the plurality of Christian actors and forces already in the early phase of European overseas expansion in the sixteenth century.

\subsection{Pretercolonial Contexts}

Paolo Aranha, in his contribution to the proceedings of the Sixth International Munich-Freising Conference, describes the establishment of colonial power structures in early modern Portuguese Goa. In his opinion, Portuguese rule there can be described as "dominance without hegemony." In addition, "Christianity endowed the Goan local elites with tools to play strategically and cunningly with the colonial power" (MFC VI, 306). Aranha therefore questions traditional dichotomies such as colonial/noncolonial and asks for a wider spectrum of variations between these two extremes.

\subsection{A Typology of Different Christian Centers}

The Sixth International Munich-Freising Conference focused primarily on various centers of Christian diffusion and expansion. In his commentary on the conference, Hartmut Lehmann suggests a "typology of different Christian centers" (MFC VI, 378) - theological and political, as well as centers of transregional expansion, resulting from voluntary or forced migration. This list could be extended with organizational, financial, or demographic centers, as well as focal points of momentum and discourse. Lehmann also suggests that we complement the category of "polycentric structures" with the concept of "multipolar networks" in the history of world Christianity (MFC VI, 378). He warns us not "to replace the previous history of European/North American missions-written partly from a triumphalist perspective-with a history of non-Western Christian self-determination, which equals an anti-European/ anti-North American triumphalism" (MFC VI, 378). Rather, he advocates a 
nuanced perspective, which in every concrete case investigates "the relationship between the local agency of the non-Western Christian communities and churches, and the heteronomous influences, the short-term and long-term effects of the missionary activities planned in Europe and North America" (MFC VI, 378). This suggestion should definitely be taken into account. At the same time, it also requires traditional church historians to take note of the diversity of indigenous initiatives and of non-Western native agency, something that has not yet been fully realized.

\subsection{Polycentric Structures as Networks of Communications}

Wolfgang Lienemann, in his commentary on the Sixth International MunichFreising Conference, draws on Niklas Luhmann's world society theory to describe "polycentric structures" as "different networks of communication" and distinguishes between various levels of interaction: (1) centered, peripheral, and polycentric forms of interaction among Christian communities, churches, and church groups; (2) processes that result in an expansion, increase, intensification, and routinization of communication; (3) such processes leading to the emergence of different and variable structures in central, regional, local, or polycentric forms, for example, institutions, legal and financial structures, orders of competency, language rules, and expansive power structures; and (4) processes that result from all that and have structure-building effects as precursors, milestones, stages, and periods on the way toward the current form of world Christianity (MFC VI, 390). In regard to the project of a future history of world Christianity, this culminates in the suggestion "to observe and describe 'polycentric structures' as different networks of communication: some exist relatively unconnected next to each other, some overlap on the margins, others are related to each other, some exhibit a high internal communication density, others only loose contacts" (MFC VI, 390).

\subsection{Polycentricity and the Concept of Transculturation}

Klaus Hock, in his contributions to the festschrift and MFC VI, has shown how a "transculturation" approach relates to the program of a "polycentric history of Christianity" as developed by Koschorke and the "Munich School." He appreciates that the concept of polycentricity intends "to capture nuances, synthetizations, overlappings, interferences, contradictions, idiosyncrasies etc. in all their complexity" (MFC VI, 401). In this way, it becomes possible, on the one hand, to reconstruct "the mutual interconnections and repercussions between Europe and the non-Western world" and, on the other hand- "while avoiding the danger of dualistic ways of relating (Europe vs. non-Europe)"-to capture the specific profile of regional developments and local forms of Christianity and integrate both into a higher-level perspective (MFC VI, 401). 
The U.S. systematic theologian Joy A. McDougall points to new forms of access to the "prophetic potential of Christian traditions" (MFC VI, 396) that result from the program of a polycentric history of Christianity, with its "more pluralistic account of the origins and the global spread of Christianity" (MFC VI, 395). This enables "creative reconstructions of doctrines" (MFC VI, 396-97). McDougall draws attention to the methodological possibilities opened by this new research perspective and underlines the fact that "a more diverse generation of scholars-significantly more women and more scholars from the global South - need to be trained and shape [the] future agenda" (MFC VI, 398) of historical research.

\subsection{Polycentric Structures and New Historiographical Approaches}

Reinhard Wendt, who teaches global history at the University of Hagen, stressed in a comment to the Fifth International Munich-Freising Conference that from a global history perspective the plurality of developments in the history of Christianity has to be taken into account when integrating the history of Christianity into the general history of globalization. ${ }^{7}$ On the one hand, the missionaries made use of existing transcontinental structures and ways of communication. On the other hand, the

observation and analysis of transcontinental religious contacts, structures, and networks ... allows us to perceive a plurality of actors who took part in these processes and also makes visible the emergence of a polycentric, multifaceted Christian-religious world. This emphasizes that globalization was not just in the service of metropoles and centers and did not result in a global homogeneity of the forms of cultural expression. While homogenizing tendencies cannot be denied, they were also counteracted by contrary trends of mixing the imported with the existing, resulting in new accentuations, the development of something distinctly one's own, as well as repercussions from the peripheries to the metropolis, and also enabled contacts among one another, independent of European influences. ${ }^{8}$

Therefore, "an analysis of transcontinental religious networks is appropriate to produce valuable indicators and facts for a general history of globalization and processes of globalization." Likewise, it seems advisable to relate the debate about a polycentric history of Christianity to currently emerging concepts of a "shared history," "connected history," and "entangled history," as well as 
other concepts of a transcontinental history of interactions, and to identify mutual impulses.

1.9. What Is the Object of a History of World Christianity?

Who defines what is "Christian"? And how can the plurality of Christianity since its very beginning be reconciled with its claim to universality? These questions are addressed by Peter Bräunlein from the perspective of the anthropology of Christianity in his contribution to the festschrift. In his response to these questions Koschorke has argued that the historian of Christianity has to start from the self-understanding of historical actors. The question of normative criteria can only be discussed in a second step, preferably through a historical investigation of debates about these very questions. These referred, for example, to the issue of heresy and orthodoxy in the ancient church, along with the many very different answers to these questions. Likewise, the ecumenical movement in the twentieth century had to debate about the incompatibility of Christianity and apartheid and about the biblical legitimacy of the African tradition of polygamy. The first of these led to the exclusion of South African churches supporting apartheid; the second, to the inclusion of the Kimbanguist church in the World Council of Churches.

\subsection{An Inclusive Academic Perspective on World Christianity}

Johannes Meier, a church historian and specialist in Jesuit studies, draws attention to the genius loci of the Munich-Freising conferences-the medieval bishop Otto von Freising, who in the twelfth century was the first historian to report on the legendary "Prester John" and the East Syriac "Church of the East," thus linking the Christian Europe and the Christian Asia of his time in an unprecedented way. Meier points to the importance of including all "areas of world Christianity" (MFC VI, 427) in the project of a history of world Christianity-including Latin America and Francophone Africa. At the same time, he stresses the necessity of international cooperation that goes beyond the English-speaking academic community. This call for a wider perspective on world Christianity was the starting point of Klaus Koschorke's work in Munich, which programmatically included Latin America, together with Asia, Africa, and Oceania, in the project of an integrated "extra-European" or "non-Western" history of Christianity. Johannes Meier's reminder not to limit this enterprise to English-speaking academia and to continue cooperation with scholars from the Spanish-speaking (and Francophone) world is well taken and brings us to the second section of this article: some important issues regarding challenges and further perspectives in the history of world Christianity, as seen by the "Munich School." 


\section{Further Perspectives and Challenges in the History of World Christianity}

\subsection{Questions of the Geographic Horizon: Interacting Regional Histories}

Arun Jones has recently stressed the need to overcome the dichotomy of Western/non-Western and other binary categories that have become dominant in the study of world Christianity. He argues that increasing global connectedness-which blurs existing boundaries between societies, nations, and cultures-and the exchange of ideas around the globe increasingly challenge frameworks of analysis that are based on a limited geographic horizon. ${ }^{10}$ Similar questions may be raised with regard to quite a number of significant studies that look at Christian history in separate-regional or continentalcontexts. Various such projects have been undertaken in the past thirty or forty years. As such they were a sign of great progress, compared with earlier mission historiography that had focused primarily on Euro-American initiatives and missionary agency. Instead it became programmatic to present Christian history in the global South as "the story of the creative reception and incarnation of the Gospel in the particular regions and cultures, in contrast to a recounting of missionary endeavours." ${ }^{\prime 1}$ Such projects were first realized on a national level (e.g., in India, as a result of the "Church History Association of India," which was revived in the late 1960s). They were followed by similar initiatives on a continental level, first for Latin America (the foundation of the "Commission for the Study of Church History in Latin America" in 1973) and later for Asia, Africa, and Oceania as well. To mention just one prominent example: Ogbu U. Kalu's African Christianity: An African Story aims at telling "the story of African Christianity, not Christianity in Africa, as an African story by intentionally privileging the patterns of African agency without neglecting the noble roles played by missionaries." ${ }^{\prime 2}$ Impressive as these and other projects have been, it will nevertheless be necessary to integrate them into a wider concept and to describe the history of world Christianity as a history of multidirectional transregional and transcontinental interactions. This history still needs to be written.

The same also applies to the historiography of Christianity in its traditional centers in the Northern Hemisphere. The classical history of European (or American) churches and communities had been outside the focus of former projects of the "Munich School." But they too need to be placed within the wider context of world Christianity and analyzed in their interactions and mutual exchanges with other regions of the Christian world, beyond traditional missionary links and networks. As far as the United States is concerned, Jehu J. Hanciles recently has spoken of the process of a "de-Europeanization of American Christianity," due to the rising importance of immigrant congregations and their impact on American religious life. ${ }^{13}$ In a very interesting case study Jon 
Bialecki has traced the complex influence that developments in global Pentecostalism had on the Fuller School of World Missions and on important figures in Third Wave evangelicalism such as John Wimber and C. Peter Wagner. ${ }^{14}$ And looking at Germany, a recent research project may be mentioned that deals with the multifaceted relationship between German Protestant churches and missions and those in southern Africa in the twentieth century, especially during the apartheid era. One of the remarkable insights of this project has been the extent to which debates within the ecumenical movement and parts of German Protestantism not only influenced South African developments (and supported Christian antiapartheid movements in the region); these debates, reversely, also had a deep impact on the structures and modes of decision making within the German Protestant church itself. ${ }^{15}$ To take another example: the Barmen Declaration of 1934, a local event and product of the German Kirchenkampf, quickly gained ecumenical significance after 1945 and inspired Christian resistance to authoritarian regimes in Asia (Korea), southern Africa, and Latin America in the 1970 and 1980s; and Dietrich Bonhoeffer, a martyr under the Nazi regime, was recognized as an ecumenical figure outside of Germany immediately after his death in 1945, whereas his official reception in Protestant Germany only slowly followed that of the international ecumenical community. ${ }^{16}$ Examples such as these show that, on the one hand, it is not too difficult to place traditional topics of church history on an enlarged map of global Christianity. On the other hand, they mark an exciting challenge for the future.

\subsection{Current Debates About "Transmission" and "Appropriation" in the History of World Christianity}

A recent debate on the Yale-Edinburgh Missions list-an e-mail forum of exchange about historical aspects of the missionary movement and the development of world Christianity-focused on the relation between Western missionary "transmission" and indigenous "appropriation" of the Gospel in the spread of Christianity. This issue is closely related to a problem that has been intensively discussed in the context of the "Munich School"- the relation between continually developing new local versions of Christianity and overarching structures in different periods of its global history. At the same time, the MISSIONs list debate allows new insights regarding these problems.

One aspect is the increased awareness of the dialectic interchange between transmission and appropriation: the two processes cannot be clearly separated. "My only note," writes Thomas Harvey, for example, referring to Chinese Christianity in the early twentieth century,

would be that transmission and appropriation are inextricably entwined. My own research on the appropriation of Christianity 
and its transmission through persons such as Wang Mingdao, John Sung or Jing Dianying (Jesus Family), bring to light how appropriation shapes transmission that in turn impacts appropriation. Thus, one finds in the preaching of Wang Mingdao, or the testimonies of John Sung or the hymns of Jing Dianying modes that at once resonate with those patterned after those of foreign missionaries yet creatively and distinctively modified, adapted and transformed so as to be more fitting to their understanding, experience and sense of calling. (September 17, 2014) ${ }^{17}$

Under these circumstances, what is necessary is a more refined analysis of the various forms and elements of appropriation-including the reception as well as the refusal and the partial selection of the missionary message or the integration of biblical elements into a heterogeneous religious, philosophical, or cultural framework.

Finding the right balance between both perspectives should be an ongoing task: "Global Christianity is a result of successful missionary transmission and indigenous appropriation and it seems to me that it is helpful to balance these two aspects in appreciation and evaluation," says Richard Haney (September 17, 2014).$^{18}$ This principle should be understood as a permanent challenge and be applied not only to recent developments but also to different epochs and varied regional and cultural contexts.

At the same time, "missionary," even during the high times of the nineteenth century, was never the same as "Western." We should therefore pay attention to contemporary as well as to historical regional missionary initiatives. "It is a common misconception," says Kirsteen Kim, "that in the context of world Christianity missions ceased. . . . [W]orld, transnational and cross-cultural missionary activity continues to thrive, in various forms, both from the West but also from places and in directions that Western commentators had not expected. The study of such contemporary missionary movements, and the local reasons behind them, is a much neglected area (perhaps partly because the sources are not so readily to hand as those of Western missions ...) but one which is of great importance for understanding world Christianity" (September 17, 2014). ${ }^{19}$

This analysis of the contemporary situation offers an opportunity to think about the associated difficulties concerning a historical investigation into related indigenous missionary movements in the past-which always has been a crucial concern of the "Munich School" and which in regard to the availability of sources often presents even greater difficulties. A major element of the Munich projects over the last two decades has been to make such sources for earlier historical periods since the sixteenth century available, including through the documentary source book, ${ }^{20}$ as well as the research project 
currently conducted in Munich and Hermannsburg on indigenous Christian journals and periodicals around 1900. ${ }^{21}$

\subsection{The Fluid Character of Christian Movements and the Contributions of Religious Studies and the Anthropology of Christianity}

The "history of Christianity in the non-Western world" as developed by Klaus Koschorke in the context of the academic discipline of church history focuses mainly on churches as institutions and the plurality of Christian communities. Its perspective on indigenous Christianity in Asia, Africa, and Latin America and antimissionary movements for emancipation and independence also often concentrates on the manifold forms of ecclesial Christianity. Despite the attention being paid to important movements beyond specific churches, such as, for example, the Taiping movement in nineteenth-century China, a result of this focus has been that the fluid character of many developments beyond or even within these churches has not been given similar attention. The decisive role of the Pentecostal movement in the history of Christianity in the twentieth century, for example, has therefore not always been highlighted enough in the work of the "Munich School."22 Especially anthropological and ethnographic approaches, as well as newer theoretical contributions from religious studies, make visible a complexity that cannot be represented in a historical approach focusing mainly on instituted forms of Christianity. ${ }^{23}$ This also is related to a further engagement with important topics that transcend the history of specific churches and movements, for example, "healing" or "prayer," which have to be investigated from an interdisciplinary perspective together with religious studies, anthropology, and other cultural studies and social scientific approaches but also together with cognitive science and psychology. ${ }^{24}$

This also brings to mind the question of the "mixing" of religious traditions, which for a long time has been discussed under the rubric of "syncretism." Especially an anthropology of Christianity as well as a transcultural approach (as advocated by Klaus $\mathrm{Hock}^{25}$ ) point to the limits of previous conceptions. New forms of interdisciplinary reflection about the categories of "Christianity" and "Christian identity" can provide new insights beyond traditional perspectives from the discipline of church history. In approaching this topic, a concept such as the "politics of religious synthesis" might be helpful, referring to the power dimension and processual nature of the development and labeling of syncretic forms. ${ }^{26}$ In addition to this, we have to take into account phenomena of a complete integration of Christian elements into, for example, traditional Andean religion or the Afro-Brazilian religion of Candomblé, which could be described with the term exculturation (as suggested by Ina Rösing and Hermann Brandt). ${ }^{27}$ From a religious studies perspective, the development of categories to describe the complex relationship within Christian traditions and between different religions 
is still rudimentary. ${ }^{28}$ This shows that the external borders of a history of world Christianity are yet to be drawn. Does it include the selective reference to Christian symbols, such as the use of the Bible as a "magical" object in the context of African traditional religion or the popularity of Christian marriage ceremonies in Japan? And if so, how can such phenomena be described in a way that keeps them relevant for a history of Christianity without at the same time subjecting them to a harmonizing and standardizing Christian perspective? Religious studies itself has not yet overcome its European and Christian missionary roots in this regard. An interdisciplinary engagement with Christianity and its global history, however, can contribute much to the development of an academic study of religion that finds new ways of description beyond the concept of "syncretism."

\subsection{The History of World Christianity as Part of a Global History of Religion}

Christianity as a global movement had a deep impact on globalizing trends in other religious contexts as well. This can be seen, for example, in the interaction between the international missionary movement and the "revival" and "awakening" of traditional religions in Asia around 1900, which, at the same time, changed the character of these beliefs. One widely discussed paradigm is provided by the debates about "Buddhist modernism," which-particularly in the case of Sri Lanka-has also been labeled as "Protestant Buddhism." In its classic interpretation, this revivalist movement includes an emphasis on the rational elements in the Buddhist tradition, as well as an increased focus on the laity in the context of the Buddhist revival-as opposed to the traditional privileges of the sangha. Even more interestingly, organizational structures as well as methods of propaganda were appropriated from the Protestant missionary movement, leading to the founding of a "Young Men's Buddhist Association" in 1898-as well as a Young Men's Hindu Association and so on; the establishment of "Buddhist Sunday school"; and the heavy use of journals, periodicals, and the printing press, including the publishing of a "Buddhist catechism." At the same time, Protestant Buddhism has classically been understood as a central aspect of internationalizing tendencies in the Buddhist world in reaction to and in interaction with the modern Christian missionary movement. ${ }^{29}$ The Maha Bodhi Society, co-founded by Anagarika Dharmapala in 1891, has been called the "first international Buddhist society,"30 and in the same year, Henry S. Olcott organized an international meeting of Buddhists from Sri Lanka, Burma, China, and Japan. Later, an "International Buddhist Young Men's Association" was founded in Tokyo, Japan (1903), followed by a "World's Buddhist League" in 1925. Likewise, throughout the twentieth century, inspiration taken from Christian missionary strategies led to the creation of Buddhist missionary societies especially in Sri Lanka, Burma, Thailand, Japan, and China. ${ }^{31}$ 
While the classic example of "Buddhist modernism" in Sri Lanka has recently been subject to renewed debate, and new studies point to more nuanced evaluations of these interactions, ${ }^{32}$ it still stands as a paradigmatic example of the necessity to treat the history of world Christianity as part of a larger global history of religion. Similar observations are also possible in other religious contexts, such as in India regarding Hinduism and Islam, where the adoption of new missionary styles and the creation of missionary societies in the second half of the nineteenth century are visible signs of such mutual influences and interactions with the Christian missionary movement. ${ }^{33}$ In regard to Bombay's modernity in the nineteenth century and the development of Muslim and Hindu reformist organizations, Nile Green has argued that "this new culture cannot be separated from the organizational example of the Christian missionary associations. ${ }^{\prime 34}$ Other recent studies have detailed the influence of Christian practices of preaching on Saivite sermons in South India. ${ }^{35}$ Whereas cross-cultural studies in a given local or regional context have become a well-established field of research in mission studies and intercultural theology, the question of the globalizing impact of the missionary movement on other religious contexts opens new avenues of research, which are of great importance for a future history of world Christianity.

\subsection{The History of World Christianity and a Global History of Migration}

Migration movements and the formation of diasporas represent another field of research that is of growing importance for future studies in the history of world Christianity. Firmly rooted in the biblical tradition ("A wandering Aramean was my ancestor," Deut. 26:5), the experience of migration played a major role in the early spread of Christianity both in New Testament times and in subsequent periods. It also was crucial for Andrew F. Walls's description of the history of Christianity as a series of shifts of its "center of gravity," engendered by migration and cross-cultural expansion. In Wall's analysis, each epochal transformation from the first to the twentieth century was marked by extensive migration and contributed significantly to the polycentric structures of world Christianity ${ }^{36}$ Certain paradigms of transregional migration have been intensively scrutinized in recent times. This applies specifically to the concept of the "black Atlantic," in its relevance for the transcontinental spread of Christianity through forced and voluntary migration from the sixteenth to the twentieth century ${ }^{37}$ But there are many other migration movements and ethnic diasporas that played an important role in the polycentric diffusion and making of world Christianity. They deserve similar attention.

Some of these diasporas have been mentioned at former International Munich-Freising Conferences but have not been discussed in detail. Indian Christians-circulating in the nineteenth century's British Empire in the context 
of the indentured labor system-provide one example. Their presence repeatedly led to the establishment of new (or the reinforcement of already-existing) Indian Christian congregations in regions far away from India, such as South Africa, East Africa, the Caribbean, Fiji, Mauritius, and, as a matter of course, South Asia (Sri Lanka, Singapore, Myanmar, Malacca). The Chinese diaspora provides another impressive example-illustrated by the fact that Protestant missionary pioneers, such as Robert Morrison and Karl Friedrich Guetzlaff, started their work outside imperial China, which in the early nineteenth century was barred to them. One hundred years later prominent members of the Protestant Chinese intelligentsia, some of whom were to play an important role in Republican China, were educated outside of China. Sun Yat-sen himselffounder and first provisional president of Republican China-belonged to this elite, which had been converted to Christianity in exile (Hawaii, Japan, Hong Kong). There exist various regional case studies for the Chinese diaspora in Malacca, Thailand, and Indonesia. What is needed is a general survey and systematic research into its role in the making of Chinese Christianity. Likewise, Chinese Christian diaspora communities played an important role in the history of Christianity in neighboring countries such as Vietnam..$^{38} \mathrm{~A}$ third Asian example that deserves closer examination is provided by Korean Christian missions to neighboring countries and other continents. ${ }^{39}$

In this vein, "Migration and the Making of Global Christianity" is the title of a major research project currently being prepared by Jehu J. Hanciles. It aims "to provide a historical assessment of the Globalization of Christianity with migration as the central lens or explanatory key." ${ }^{40}$ It could be said that the variety of ethnic Christian diasporas as a basis of future transregional, polycentric, and multidirectional expansions of Christianity will be of crucial importance for this and related research projects in the future.

These are some of the current and future challenges for the study of world Christianity and a future history of world Christianity from a polycentric perspective. The work of the "Munich School" over the last two decades as well as future research projects by its members should be understood as contributions to such a project. Hopefully, the current debates and further perspectives outlined here will be supplemented by even more fruitful exchanges about changed maps, polycentric structures, and transcontinental links in the history of world Christianity.

Adrian Hermann is an assistant professor of religious studies and world Christianity in the Department of Protestant Theology, Universität Hamburg, Germany. His work focuses on the global history of the concept of "religion" and the religious history of the globalized world. His main contributions to the "Munich School" deal with conceptual issues in studying 
world Christianity and with the history of Christianity in the Philippines around 1900. He recently published his first book, called Unterscheidungen der Religion: Analysen zum globalen Religionsdiskurs und dem Problem der Differenzierung von "Religion" in buddhistischen Kontexten des 19. und frühen 20. Jahrhunderts (Göttingen: Vandenhoeck und Ruprecht, 2015), and is the co-editor (with Klaus Koschorke) of Polycentric Structures in the History of World Christianity (Wiesbaden: Harrassowitz, 2014).

Ciprian Burlacioiu is a researcher and lecturer (Privatdozent) at the chair for Early and Global History of Christianity, Faculty of Protestant Theology, Ludwig-Maximilians-Universität München, Germany. He is a Romanian, studied Orthodox theology, and received a Ph.D. from the University of Bucharest with a dissertation on ecumenical models of church union. His habilitation thesis on the history of the African Orthodox Church between the United States, South Africa, and East Africa (1920s to 1950s) was published as a monograph in 2015. His current research deals with the meaning of migration and diaspora in the general history of Christianity and especially with a case study on the importance of migration for the development of a mission-independent Christianity in southern Africa around 1900. He teaches courses on classical subjects of church history, as well as on a wide range of topics related to the history of world Christianity.

\section{NOTES}

1. For current debates in the United States, see Theology Today 71, no. 2 (2014), edited by Joy A. McDougall, and her editorial in that issue titled "Contemporary Landscapes and New Horizons: The Changing Maps of World Christianity" (159-63).

2. These are Klaus Koschorke, Frieder Ludwig, and Mariano Delgado, eds., Außereuropäische Christentumsgeschichte (Asien, Afrika, Lateinamerika) 1450-1990, in cooperation with Roland Spliesgart, 4th ed. (Neukirchen-Vluyn, Germany: Neukirchener Verlag, 2012); English translation: Klaus Koschorke, Frieder Ludwig, and Mariano Delgado, eds., A History of Christianity in Asia, Africa, and Latin America, 1450-1990: A Documentary Sourcebook, in cooperation with Roland Spliesgart (Grand Rapids: Eerdmans, 2007); Klaus Koschorke, Adrian Hermann, Ciprian Burlacioiu, and E. Phuti Mogase, eds., Discourses of Indigenous Christian Elites in Colonial Societies in Asia and Africa Around 190o. A Documentary Sourcebook from Selected Journals (Wiesbaden: Harrassowitz, 2016); Klaus Koschorke, ed., Konfrontation und Interaktion kolonialer und indigener Christentumsvarianten, Studies in the History of Christianity in the Non-Western World (Asia, Africa, Latin America) 1 (Göttingen: Vandenhoeck und Ruprecht, 1998); Klaus Koschorke, ed., Transkontinentale Beziehungen in der Geschichte des Außereuropäischen Christentums/Transcontinental Links in the History of NonWestern Christianity, Studies in the History of Christianity in the Non-Western World (Asia, Africa, Latin America) 6 (Wiesbaden: Harrassowitz, 2002); Klaus Koschorke, ed., 
African Identities and World Christianity in the Twentieth Century, Studies in the History of Christianity in the Non-Western World (Asia, Africa, Latin America) 10 (Wiesbaden: Harrassowitz, 2006); Klaus Koschorke, ed., Falling Walls: The Year 1989/90 as a Turning Point in the History of World Christianity/Einstürzende Mauern: Das Jahr 1989/9o als Epochenjahr in der Geschichte des Weltchristentums, Studies in the History of Christianity in the Non-Western World (Asia, Africa, Latin America) 15 (Wiesbaden: Harrassowitz, 2009); Klaus Koschorke, ed., Etappen der Globalisierung in christentumsgeschichtlicher Perspektive/Phases of Globalization in the History of Christianity, Studies in the History of Christianity in the Non-Western World (Asia, Africa, Latin America) 19 (Wiesbaden: Harrassowitz, 2012); Klaus Koschorke and Adrian Hermann, eds., Polycentric Structures in the History of World Christianity/Polyzentrische Strukturen in der Geschichte des Weltchristentums, Studies in the History of Christianity in the Non-Western World (Asia, Africa, Latin America) 25 (Wiesbaden: Harrassowitz, 2014); Ciprian Burlacioiu and Adrian Hermann, eds., Veränderte Landkarten: Auf dem Weg zu einer polyzentrischen Geschichte des Weltchristentums; Festschrift für Klaus Koschorke zum 65. Geburtstag (Wiesbaden: Harrassowitz, 2013); Frieder Ludwig, Zwischen Kolonialismuskritik und Kirchenkampf: Interaktionen afrikanischer, indischer und europäischer Christen während der Weltmissionskonferenz Tambaram 1938, Studies in the History of Christianity in the Non-Western World (Asia, Africa, Latin America) 5 (Göttingen: Vandenhoeck und Ruprecht, 2000); Friedemann Burkhardt, Christoph Gottlob Müller und die Anfänge des Methodismus in Deutschland (Göttingen: Vandenhoeck und Ruprecht, 2003); Roland Spliesgart, "Verbrasilianerung" und Akkulturation: Deutsche Protestanten im brasilianischen Kaiserreich am Beispiel der Gemeinden in Rio de Janeiro und Minas Gerais (1822-1889), Studies in the History of Christianity in the Non-Western World (Asia, Africa, Latin America) 12 (Wiesbaden: Harrassowitz, 2006); Andreas Müller, Das Konzept des Geistlichen Gehorsams bei Johannes Sinaites: Zur Entwicklungsgeschichte eines Elements orthodoxer Konfessionskultur (Tübingen: Mohr Siebeck, 2006); Ciprian Burlacioiu, "Within Three Years the East and the West Have Met Each Other": Die Genese einer missionsunabhängigen schwarzen Kirche im transatlantischen Dreieck USA-Südafrika-Ostafrika (1921-1950), Studies in the History of Christianity in the NonWestern World (Asia, Africa, Latin America) 27 (Wiesbaden: Harrassowitz, 2015).

3. See Koschorke and Hermann, eds., Polycentric Structures in the History of World Christianity, 67; hereafter cited as MFC VI.

4. Burlacioiu and Hermann, Veränderte Landkarten; and MFC VI.

5. The following summary draws greatly on the responses and comments presented by Klaus Koschorke in his "Rückblicke, Ausblicke," in MFC VI, 435-56. All translations are ours. The full versions of the comments and responses can be found in those volumes.

6. In Burlacioiu and Hermann, Veränderte Landkarten, 72.

7. Reinhard Wendt, "Globalisierung in christentumsgeschichtlicher Perspektive," in Etappen der Globalisierung in christentumsgeschichtlicher Perspektive/Phases of Globalization in the History of Christianity, ed. Klaus Koschorke, Studies in the History of Christianity in the Non-Western World (Asia, Africa, Latin America) 19 (Wiesbaden: Harrassowitz, 2012), 373-76, at 375-76. 
8. Ibid., 375 .

9. Ibid., 376.

10. See Arun Jones, "Scholarly Transgressions: (Re)writing the History of World Christianity," Theology Today 71, no. 2 (2014): 221-32, at 225-27.

11. Lukas Vischer, ed., Towards a History of the Church in the Third World: The Issue of Periodisation (Bern: Ecumenical Association of Third World Theologians, 1985), 131.

12. Ogbu U. Kalu, ed., African Christianity: An African Story (Pretoria: University of Pretoria Press, 2005), iv.

13. Jehu J. Hanciles, Beyond Christendom: Globalization, African Migration, and the Transformation of the West (Maryknoll, N.Y.: Orbis, 2008), 276ff., $293 \mathrm{ff}$.

14. Jon Bialecki, "The Third Wave and the Third World. C. Peter Wagner, John Wimber, and the Pedagogy of Global Renewal in the Late Twentieth Century," Pneuma 37, no. 2 (2015): 177-200.

15. See Hanns Lessing, Julia Besten, Tilman Dedering, Christian Hohmann, and Lize Kriel, eds., The German Protestant Church in Colonial Southern Africa: The Impact of Overseas Work from the Beginnings Until the 1920s, Studies in the History of Christianity in the Non-Western World (Asia, Africa, Latin America) 21 (Wiesbaden: Harrassowitz, 2012); Hanns Lessing, Tilman Dedering, Jürgen Kampmann, and Dirkie Smit, eds., Contested Relations: Protestant Controversies Between Southern Africa and Germany from the 193os to the Apartheid Era, Studies in the History of Christianity in the Non-Western World (Asia, Africa, Latin America) 26 (Wiesbaden: Harrassowitz, 2015).

16. See Tim Lorentzen, “'Geschenk ökumenischer Brüderschaft': Beobachtungen zur polyzentrischen Strukturen der Bonhoeffer-Rezeption," in MFC VI, 317-34.

17. See http://mailman.yale.edu/mailman/private/missions/2014-September/ooo482. html (archive available to list members).

18. See http://mailman.yale.edu/mailman/private/missions/2014-September/ooo477. html (archive available to list members).

19. See http://mailman.yale.edu/mailman/private/missions/2014-September/ooo479. html (archive available to list members).

20. Koschorke, Ludwig, and Delgado, History of Christianity in Asia, Africa, and Latin America.

21. German Research Foundation research project "Indigenous Christian Elites from Asia and Africa Around 1900 and Their Journals and Periodicals. Patterns of Cognitive Interaction and Early Forms of Transregional Networking," lead investigators Klaus Koschorke and Frieder Ludwig. For details, cf. the concluding third section of the introduction in the present issue of the Journal of World Christianity.

22. From the copious literature, see only Allan H. Anderson, Michael Bergunder, André Droogers, and Cornelis van der Laan, eds., Studying Global Pentecostalism: Theories and Methods (Berkeley: University of California Press, 2010); Allan H. Anderson, To the Ends of the Earth: Pentecostalism and the Transformation of World Christianity (Oxford: Oxford University Press, 2013).

23. The fluid character of religion is stressed, e.g., in Thomas Tweed, Crossing and Dwelling: A Theory of Religion (Cambridge: Harvard University Press, 2006). On the "anthropology of Christianity," see Fenella Cannell, ed., The Anthropology of Christianity 
(Durham: Duke University Press, 2006); Matthew Engelke and Matt Tomlinson, eds., The Limits of Meaning: Case Studies in the Anthropology of Christianity (New York: Berghahn, 2006); Jon Bialecki, Naomi Haynes, and Joel Robbins, "The Anthropology of Christianity," Religion Compass 2, no. 6 (2008): 1139-58; Timothy Jenkins, "The Anthropology of Christianity: Situation and Critique," Ethnos 77, no. 4 (2012): 459-76; and the introduction and comprehensive collection of essays in a recent special issue of Current Anthropology: Joel Robbins, "The Anthropology of Christianity: Unity, Diversity, New Directions. An Introduction to Supplement 10," Current Anthropology 55, no. S10 (2014): S157-71.

24. See, for example, Candy G. Brown, ed., Global Pentecostal and Charismatic Healing (Oxford: Oxford University Press, 2011). As a great example of a fruitful combination of anthropology, sociology, cognitive science, and psychology, see Tanya M. Luhrmann, Howard Nusbaum, and Ronald Thisted, "The Absorption Hypothesis: Hearing God in Evangelical Christianity, American Anthropologist 112, no. 1 (2010): 66-78; Tanya M. Luhrmann, "A Hyperreal God and Modern Belief: Toward an Anthropological Theory of Mind," Current Anthropology 53, no. 4 (2012): 371-95. Cf. also Tanya M. Luhrmann, When God Talks Back: Understanding the American Evangelical Relationship with God (New York: Alfred A. Knopf, 2012).

25. See Klaus Hock, "Transkulturation und Religionsgeschichte," in Religionswissenschaft, ed. Michael Stausberg (Berlin: de Gruyter, 2012), 435-48.

26. See Charles Stewart and Rosalind Shaw, eds., Syncretism/Anti-syncretism: The Politics of Religious Synthesis (London: Routledge, 1994).

27. See Ina Rösing, Die heidnischen Katholiken und das Vaterunser im Rückwärtsgang: Zum Verhältnis von Christentum und Andenreligion (Heidelberg: Winter, 2001); Hermann Brandt, Die heilige Barbara in Brasilien: Kulturtransfer und Synkretismus in Brasilien (Erlangen: Universitätsbibliothek Erlangen, 2003). See also the contributions of Paul Gifford and Roland Spliesgart in Burlacioiu and Hermann, Veränderte Landkarten.

28. See Hock, "Transkulturation und Religionsgeschichte."

29. See Richard F. Gombrich, Theravada Buddhism: A Social History from Ancient Benares to Modern Colombo, 2nd ed. (London: Routledge, 2006); Heinz Bechert, Buddhismus, Staat und Gesellschaft in den Ländern des Theravāda-Buddhismus, vol. 1, Grundlagen: Ceylon (Frankfurt am Main: Alfred Metzner, 1966), 95-108.

30. Bechert, Buddhismus, 96.

31. See Jonathan S. Walters, Encyclopedia of Religion, 2nd ed., s.v. "Missions: Buddhist Missions"; Vincent Goossaert and David A. Palme, The Religious Question in Modern China (Chicago: University of Chicago Press, 2011), 76.

32. See Elizabeth J. Harris, Theravāda Buddhism and the British Encounter: Religious, Missionary, and Colonial Experience in Nineteenth Century Sri Lanka (London: Routledge, 2006); Anne M. Blackburn, Locations of Buddhism: Colonialism and Modernity in Sri Lanka (Chicago: University of Chicago Press, 2010).

33. See Nile Green, Bombay Islam: The Religious Economy of the West Indian Ocean, 1840-1915 (New York: Cambridge University Press), 31-34.

34. Ibid., 32. 
35. See Bernard Bate, "Arumuga Navlar, Saivite Sermons, and the Delimitation of Religion, c. 1850," Indian Economic and Social History Review 42, no. 4 (2005): 467-82; Bernard Bate, "The Ethics of Textuality: The Protestant Sermon and the Tamil Public Sphere," in Ethical Life in South Asia, ed. Anand Pandian and Daud Ali (Bloomington: Indiana University Press, 2010), 101-15.

36. See, for example, Andrew F. Walls, "Mission and Migration: The Diaspora Factor in Christian History," in Global Diasporas and Mission, ed. Chandler H. Im and Amos Yong (Cornwall, U.K.: Regnum Books, 2014), 19-37.

37. See Paul Gilroy, The Black Atlantic: Modernity and Double-Consciousness (London: Verso, 1993).

38. On the role of the Chinese diaspora in the development of Catholicism in Vietnam, see Peter C. Phan, "Chinese Catholics in Ho Chi Minh City (Saigon), Vietnam, 1865-2012," in MFC VI, 141-52.

39. See Kyo S. Ahn, "Korea as an Early Missionary Center: Korean Missionaries Around 1910 in Northeast Asia and Beyond," in MFC VI, 99-110; cf. also Kirsteen Kim, "South Korea as a Missionary Centre of World Christianity: Developments in Korean Protestantism After the Liberation (1945)," in MFC VI, 111-29. Some recent essays on Korean, Chinese, Japanese, and Filipino diaspora communities can also be found in Im and Yong, Global Diasporas and Mission.

40. Jehu J. Hanciles, "Migration and the Making of Global Christianity" (unpublished research proposal, 2014). Cf. also Jehu J. Hanciles, "God's Mission Through Migration: African Initiatives in Globalizing Mission," in Evangelical, Ecumenical, and Anabaptist Missiologies in Conversation: Essays in Honor of Wilbert R. Shenk, ed. James R. Krabill, Walter Sawatsky, and Charles E. Van Engen (Maryknoll, N.Y.: Orbis, 2006), 58-66. 